\title{
The Crowd-Out Effect of Government Debt on Firm Leverage
}

\author{
Xiaomiao Xia ${ }^{1}$, Jingyue Liao $^{1}$, Zitang Shen ${ }^{1}$ \\ ${ }^{1}$ Chinese Academy of Finance and Development, Central University of Fiance and Economics, Beijing, China, 100089
}

\begin{abstract}
Based on the data of 21 provinces from 2000 to 2018, this paper empirically examines the impact of government debt on corporate financing decisions, and finds that there is a negative correlation between government debt and corporate leverage. In large enterprises, private enterprises and enterprises in economically developed areas, the negative relationship is stronger. In order to deal with the potential endogenous problems, we use the government debt excluding the province GDP as the instrumental variable, and take the financial crisis and the 4 trillion policy as the division point to divide two periods of time as the robustness test. The results show that government debt crowds out corporate debt.
\end{abstract}

\section{Introduction}

The 2008 Global Financial Crisis (GFC) greatly damaged the financial systems of economies all over the world, causing the slowdown of global economic growth. To safeguard and stimulate the post-crisis domestic economy, central government enacted 4-trillion-yuan stimulus plan. After the timing launch of the stimulus package, the Chinese economy rebounded successfully and quickly, with a sharp rising of its corporate debt and household debt. Since the financial crisis in 2008 , the leverage ratio of nonfinancial corporate sectors has been rising on the whole level (Chong Ninghua et al., 2016). Under the downward pressure of the economy, how to effectively and steadily achieve "deleverage" has become a key issue for China's supply-side structural reforms, which also has become a decisive factor in whether China's economy can achieve sustainable development. Therefore, it is essential to figure out the interaction between the expansion of government debt and the increase of corporate debt.

However, there is still a lack of research on the relationship between government debt and corporate leverage, especially quantitative research discovering the effect and determination mechanisms. Most studies focused on the impact of government debt on local economic growth from a macro or regional perspective (Qiu Yuhua et al., 2015). Whether the impact of government debt on corporate leverage is "beneficial" or "harmful", research in related fields still needs further development. Demirci and Irem (2019) empirically investigate the impact of government debt on corporate financing decision based on an international resource and the results show a negative relation. Graham et al. (2015) used the 1920-2012 U.S. time series data to demonstrate a significantly negative correlation between local government leverage and firm leverage, they argue that government borrowing decision plays an important role in explaining the continuously rising trend of firm leverage in the unregulated industries.

In this paper, we combine the government's macrolevel chengtou bonds with the company's micro-level leverage, focusing on the crowd-out effect of local government debt financing on firm leverage. Quasimunicipal bonds, also known as Chengtou bonds, are urban construction and investment bonds in China. Chengtou bonds are issued by LGFVs but implicitly guaranteed by local governments as part of their financial obligations. And firm evidence from the Chinese manufacturing sector is used to verify the crowd-out effect. We further analyze whether there is a significant difference in the impact of government debt on corporate leverage in the context of heterogeneous financing frictions. Also, we examine the impact of regional factors on the crowded-out effect and find that it is more significant in the southwestern region where the legal environment and banking system are more developed. To address the concerns about the possible endogeneity that the firm-level leverage ratio and local government debt both can be affected by some mutual factors, such as macroeconomic situation, we use lagged regressors as instruments variable to check the robustness of our basic regression results.

Compared with the previous literature, the mainly contributions of this paper are: Firstly, the data of previous studies are mainly based on Western countries, and whether the results of the study are applicable to China remains to be further verified, and our paper is based on the firm-level evidence from China, using the amount of chengtou bonds in each provinces as the measurement of the government debt. Second, in addition to firm size, we distinguish the firm debt by maturity to get the subsample and further conclusion.

The remainder of this paper is organized as follows: Section 2 briefly introduces the institutional background. Section 3 and 4 presents the hypothesis and model setting. Section 5 describes the data and reports the summary statistics. Section 6 present the results for empirical 
analysis. Section 7 runs robustness test, addresses endogeneity concerns by using subsample and instrumental variables specifications. Section 8 concludes.

\section{Literature Review and Hypothesis Development}

The crowding out effect of private activities by the government has been debated in the economics literature for a long time. On the one hand, Spencer and Yohe (1970) first mentioned specific definition of the crowded-out effect in detail. Fan et al. (2012) find that issuance of government bonds crowded out firms' debt financing in developing countries. Also, Elmendorf and Mankiw (1999) suggest that the expansion of government debt could increase firm financing costs, and Hubbard (2012) points that the increasing costs are prone to discourage and even crowd out private investments. The existing literatures mainly related two kinds of rationales to explain the increasing financing cost, that is, the crowded-out effect of government financing and the re-allocation of Chinese economy.

The majority of existing literature focuses mainly on the financing cost channel through the credit market. For instance, Friedman (1978) found out that government debt financing can crowd out firm-level corporate debt financing through competition for investor funding. Graham et al. (2014) confirm that investors' portfolio optimization and adjustment are responsible for the crowd-out effect of government debt financing on firmlevel financing. Apart from the financing cost channel through credit market, non-market reallocation channel also matters in China. Different from traditional monetary and fiscal policies, non-market administrative measures force the state-owned sector to conduct special activities for smoothing the economic cycles or achieving political and economic tasks. With provincial governments' implicit guarantees, cheap credit can be channeled to the target state-owned sector through administrative orders. Given these reasons, even bearing accumulated and concentrated risks, banks still have strong incentives to fund SOEs' investments for safety.

Bases on the existing literatures as above, we propose four hypotheses:

H1: More province-level government debt leads to higher firm-level leverage ratio.

H2: Larger firms can defend crowd-out effect of government debt better than smaller firms.

H3: The crowd-out effect of government debt on firm leverage is larger in non- SOEs.

H4: The crowded-out effect of government debt on firm leverage is larger in southwestern region.

\section{Model}

We construct an empirical approach to identifying the crowding-out effect of local government debt on firm leverage based on the existing literature. Our firm-level sample covers a large scale of listed firms in China and we employ a series of econometric models.

\subsection{Benchmark model}

This benchmark econometric model is constructed in order to test the crowding-out effect:

leverage $1_{i j t}=\alpha+\beta_{1} *$ lngovdebt $_{j t}+\beta_{2} * X_{i j t}+$

$$
\beta_{3} * Z_{j t}+T_{t}+\varepsilon_{i j t}
$$

where leverage $1_{\mathrm{ijt}}$ and lngovdebt $_{\mathrm{jt}}$ respectively represents the leverage ratio of firm $i$ and the natural logarithm of local government debt in province $j$ at time $t$. To be more specific, local government debt is measured by the provincial Chengtou bonds issuance amount.

As our control variables contain both firm-level and province-level characteristics, $X_{i j t}$ and $Z_{j t}$. $X_{i j t}$ denotes a vector of firm-level characteristics, which include size of firm, profitability and tangibility. Firm size is defined as the logarithm of firm's sales and return on equity is used to measure the profitability. A vector of provincial government-level characteristics including the provincial GDP, the local government expenditure divided by GDP, the number of firms in the province, and the local government revenue divided by GDP, is denoted by $Z_{j t}$.

Furthermore, we also control for provincial and year fixed effect in order to deal with omitted variable problems that possibly exist. $T_{t}$ denotes the year fixed effect, allowing us to control for the factors that possibly have correlation with government debt. In the meantime, we recognize that some cyclical macro factors, such as macro policy shocks, may exist. Hence, we control for time-varying factors by year fixed effect to address this latent variable problem.

\subsection{Distinguishing the effects on firms with different size}

Since both of inventory and fixed assets can be used as collateral for debt financing, the size of assets is a key factor that determines the ability of firms to borrow. Larger size of the asset indicates lower degree of information asymmetry between enterprise and bank. And the stronger the company's ability to borrow, the easier it is to obtain debt financing.

To test if the local government debt impact firms with different size in distinctive ways, we employ the following specification:

$$
\begin{aligned}
& \text { leverage } 1_{i j t}=\alpha+\beta_{1} * \text { lngovdebt }_{j t}+\beta_{2} * \operatorname{size}_{i j t} \\
& +\beta_{3} * \text { lngovdebt }_{j t} * \text { size }_{i j t} \\
& +\beta_{4} * X_{i j t}+\beta_{5} * Z_{j t}+T_{t}+\varepsilon_{i j t}
\end{aligned}
$$

In this model, $\beta_{3}$, the coefficient of the interaction term of local government debt and size, is our focus.

\section{Data}

In this section, we will describe the data source and summarize the main variables used.

Due to the availability of data, the sample used in this paper is limited. we select non-financial companies of China A-share listed companies, eliminate companies with serious data shortages and exclude those are specially treated by ST. Our sample consists of 22,775 firm-year 
observations totally, covering the period from 2000 to 2018. Because provinces have different time series for the chengtou bonds issuance, and firms could also enter or exit, our sample is an unbalanced panel data.

Our data mainly comes from Wind database, National Bureau of China (NBS) and Chinese industrial enterprises database. We calculate and aggregate the issuance of deallevel chengtou bond from Wind database to obtain the local government debt.

Previous literatures measure the firm-level leverage ratio mainly through the liability divided by assets from a static perspective centered on debt level. In this paper we select two dependent variables. One is defined as the liabilities divided by assets (leverage1). The other one, leverage 2 , is the long-term liability divided by total assets.

As for the independent variables, following the literature (Ambrose et al., 2015; Bai et al., 2016; Ang et al., 2016;) on the chengtou bond market, the issuance amounts of chengtou are chosen as a proxy for local government debt, due to the high correlation between local government debt and issuance of chengtou bond. The independent variables is lngovdebt, which is defined as the logarithm of chengtou bonds issuance amount (govdebt). Also, we divide it by province GDP to get govdebt_gdp for further testing.

According to previous literatures (Irem et al.,2019; Che et al.,2019;),we control some firm-level characteristics, including firm size (Size), which is calculated by taking the logarithm of total assets, the return on equity (ROE) and tangibility, which is defined as the fixed assets divided by total liability (tangibility). From the perspectives of size, profitability, and tangibility, we try to control the potential firm-level effect.

Table1. Summary statistics
To control the macro-level effect in different provinces, we also add some province-level control variables. According to the location, we match firm-level financial data with province-level bond issuance data. To be more specific, the location of firm is the registered address, through which we can associate the firm with the province situation.

The province-level control variables include province GDP (pro_GDP), the government expenditures and revenues separately divided by province GDP (Govexpgdp, Govrevgdp), and the number of firms in this province (numoffirms).

In addition, based on firms' registration information, we also obtain some dummy variables, including SOE, Regulate, Northwest, Northeast, Southeast, Southwest, to capture the characteristics of firms for further investigation. SOEs and non-SOEs is defined based on their registration information. SOE is set to be 1 if the firm is SOEs, otherwise equal to 0. Following Yousha Liang et al(2019), the regulated industries loosely refer to public industry and utilities industry, and all the others are defined as unregulated industries. Regulate is defined to be 1 if the firm belongs to regulated industry, otherwise, Regulate equals to 0 . We also generate four dummy variables to define the location of the firm. If the firm's location is in the northwest of China, the dummy variable northwest equals to 1 , otherwise, northwest equals to 0 . We also obtain northeast, southwest and southeast in the same way.

Table 1 reports the summary statistics capturing the characteristics of local governments, firm-level characteristics.

\begin{tabular}{|c|c|c|c|c|c|}
\hline Dependent & Obs & Mean & Sd.dev & Min & Max \\
\hline Leverage1 & 21,636 & 46.598 & 148.477 & 0.708 & 13837.8 \\
\hline Leverage2 & 19,787 & 0.134 & 0.2322 & -0.0017 & 2.3684 \\
\hline \multicolumn{6}{|l|}{ Explantory } \\
\hline Lngovdebt & 22,775 & 4.7878 & 1.7577 & 0 & 8.535 \\
\hline Govdebt & 22,775 & 362.41 & 528.969 & 1 & 5091.01 \\
\hline Govdebt_gdp & 22,775 & 0.0011 & 0.0016 & 0 & 0.011 \\
\hline \multicolumn{6}{|c|}{ Firm-level Control } \\
\hline Size & 22,773 & 21.399 & 1.800294 & 10.1713 & 28.506 \\
\hline Tangibility & 22,668 & 2.843 & 82.97406 & 8.63E-06 & 8500 \\
\hline Pro_gdp & 22,775 & 22525.31 & 68480.93 & 526.82 & 919281 \\
\hline Numoffirms & 22,775 & 253.222 & 194.8448 & 1 & 584 \\
\hline \multicolumn{6}{|l|}{ Dummy } \\
\hline SOE & 22,775 & 0.3040 & 0.4600 & 0 & 1 \\
\hline Regulate & 22,775 & 0.0133 & 0.1146 & 0 & 1 \\
\hline Northwest & 22,775 & 0.0318 & 0.1755 & 0 & 1 \\
\hline Northeast & 22,775 & 0.2759 & 0.4469 & 0 & 1 \\
\hline Southwest & 22,775 & 0.0488 & 0.2155 & 0 & 1 \\
\hline Southeast & 22,775 & 0.6434 & 0.4789 & 0 & 1 \\
\hline
\end{tabular}




\section{Empirical results}

\subsection{The effect of local government debt on firm leverage level}

Based on former studies and our assumptions, we first evaluate the influence of Chinese government debt on Chinese listed firms' debt level. To represent the local government debt, we use the amount of Chengtou bond issued by the province as the independent variable where each firm is located. To describe the firm leverage, we use two leverage ratio to measure it from different perspectives: leverage1 (debt-to-asset ratio) and leverage 2 (long-term debt to asset). Leveragel evaluates the leverage of listed companies in each year and leverage2 measures the long-term debt proportion.

From the results, we find that the increase of Chengtou bond will significantly increase both the firm short-term and the long-term leverage. This effect is correspond to our former Hypothesis 1: More province-level government debt leads to higher firm-level leverage ratio.

Larger firms have a lower leverage than smaller firms. State owned enterprises have a higher long-term obligations than other companies. Firms with higher earning, which means higher ROE, will have a relevant high leverage. Firms with less tangible assets will set a lower long-term leverage ratio but a higher short-term leverage. In provinces with a better economic environment and higher GDP, listed firms will lend less debt from the market.

Table2. Crowd-out effect and Crowd-out effect of big and high-earning firms

\begin{tabular}{|c|c|c|c|c|}
\hline & \multirow{3}{*}{$\begin{array}{c}\text { Dependent Variable } \\
\text { leverage1 } \\
\text { (1) }\end{array}$} & \multicolumn{3}{|c|}{ variable: } \\
\hline & & \multirow{2}{*}{$\begin{array}{c}\text { leverage } 2 \\
\text { (2) }\end{array}$} & \multicolumn{2}{|c|}{ Leverage1 } \\
\hline & & & (3) & (4) \\
\hline \multirow[t]{2}{*}{ lngovdebt } & $-0.848 * * *$ & $-0.010 * * *$ & $-16.699 * * *$ & $-1.074 * * *$ \\
\hline & $(0.274)$ & $(0.001)$ & (3.793) & $(0.313)$ \\
\hline \multirow[t]{2}{*}{ size } & $-8.762 * * *$ & $-0.138 * * *$ & $-12.318 * * *$ & $-8.755^{* * *}$ \\
\hline & $(0.713)$ & $(0.001)$ & (1.108) & $(0.713)$ \\
\hline \multirow[t]{2}{*}{ tangibility } & $10.282 *$ & $-0.0001 * * *$ & $10.103^{*}$ & $10.114^{*}$ \\
\hline & $(5.393)$ & $(0.00001)$ & $(5.391)$ & $(5.394)$ \\
\hline \multirow[t]{2}{*}{ roe } & $0.080 * * *$ & $0.000 * * *$ & $0.082 * * *$ & -0.005 \\
\hline & $(0.019)$ & $(0.000)$ & $(0.019)$ & $(0.060)$ \\
\hline \multirow[t]{2}{*}{ soe } & -2.769 & $0.060 * * *$ & -2.264 & -2.736 \\
\hline & $(2.692)$ & $(0.007)$ & $(2.693)$ & $(2.692)$ \\
\hline \multirow[t]{2}{*}{ regulate } & -6.599 & 0.016 & -6.311 & -6.655 \\
\hline & $(5.347)$ & $(0.015)$ & $(5.344)$ & $(5.346)$ \\
\hline \multirow[t]{2}{*}{ pro_gdp } & $-0.0002 * * *$ & -0.00000 & $-0.0002 * * *$ & $-0.0002 * * *$ \\
\hline & $(0.00002)$ & $(0.00000)$ & $(0.00002)$ & $(0.00002)$ \\
\hline \multirow[t]{2}{*}{ numoffirms } & $0.049 * * *$ & 0.00002 & $0.049 * * *$ & $0.049 * * *$ \\
\hline & $(0.009)$ & $(0.00002)$ & $(0.009)$ & $(0.009)$ \\
\hline \multirow[t]{2}{*}{ lngovdebt:size } & & & $0.725 * * *$ & \\
\hline & & & $(0.173)$ & \\
\hline \multirow[t]{2}{*}{ lngovdebt:roe } & & & & 0.017 \\
\hline & & & & $(0.011)$ \\
\hline Observations & 18,398 & 17,312 & 18,398 & 18,398 \\
\hline R2 & 0.022 & 0.635 & 0.023 & 0.022 \\
\hline Adjusted R2 & -0.113 & 0.582 & 0.012 & 0.013 \\
\hline F Statistic & $44.638 * * *$ & $3,286.775 * * *$ & $41.670 * * *$ & $39.928 * * *$ \\
\hline
\end{tabular}

\subsection{Defending the crowd-out effect of big firms and high-earning firms}

According to our Hypothesis2, larger firms can defend crowd-out effect of government debt more than smaller firms.

To test this hypothesis, we run the fixed effect model considering cross items with independent variable lngovdebt and firm size or return on equity. We conclude that in Chinese market, the effect of local government debt on firm leverage is less severe in larger firms. On the contrary, larger firms try to lend more when there is a significant government action on debt market. However, in Chinese market, we fail to find any defend of highearning firms.

\subsection{The defending of crowd-out in SOE firms}

To test Hypothesis 3: The crowd-out effect of government debt on firm leverage is larger in non-SOEs. We analyze the effect of government debt from subsamples in SOEs and non-SOEs. We find that in non-SOE subsample, 
crowd-out influence of government obligation is significant on both debt to asset ratio and long-term leverage. However, in SOE subsample, we find that the local government debt doesn't significantly affect on firm's debt to asset ratio. When Chinese banks provide loans to SOE, they do not fully follow the principle of profit, but are driven by the government's invisible guarantee or the bank's policy burden. Thus, although the financing cost in debt market is enhanced by the increase of government debt, SOEs can avoid this effect through their political power and make banks lend to them in spite of the high financing cost in the short-term. Whereas, they will still bear the pressure from the increase of financing cost in the long-term

Table3. Crowd-out effect in SOEs

\begin{tabular}{|c|c|c|c|c|}
\hline & \multicolumn{2}{|c|}{ Non-SOE } & \multicolumn{2}{|r|}{$S O E$} \\
\hline & $\begin{array}{l}\text { leverage } 1 \\
\text { (1) }\end{array}$ & $\begin{array}{l}\text { leverage } 2 \\
\text { (2) }\end{array}$ & $\begin{array}{c}\text { leverage } 1 \\
\text { (3) }\end{array}$ & $\begin{array}{c}\text { leverage } 2 \\
\text { (4) }\end{array}$ \\
\hline lngovdebt & $\begin{array}{c}-1.104 * * * \\
(0.366)\end{array}$ & $\begin{array}{c}-0.010 * * * \\
(0.001)\end{array}$ & $\begin{array}{l}-0.157 \\
(0.125)\end{array}$ & $\begin{array}{c}-0.009 * * * \\
(0.001)\end{array}$ \\
\hline size & $\begin{array}{c}-7.503^{* * * *} \\
(0.902)\end{array}$ & $\begin{array}{c}-0.121 * * * \\
(0.001)\end{array}$ & $\begin{array}{c}1.506 * * * \\
(0.436)\end{array}$ & $\begin{array}{c}-0.164 * * * \\
(0.002)\end{array}$ \\
\hline tangibility & $\begin{array}{c}29.214 * * * \\
(7.444)\end{array}$ & $\begin{array}{c}-0.0001^{* * *} \\
(0.00001)\end{array}$ & $\begin{array}{l}4.344^{*} \\
(2.458)\end{array}$ & $\begin{array}{c}-0.0002^{* * *} * \\
(0.00003)\end{array}$ \\
\hline regulate & $\begin{array}{l}-7.363 \\
(6.676)\end{array}$ & $\begin{array}{c}0.038^{* *} \\
(0.017)\end{array}$ & $\begin{array}{c}-8.411 * * * \\
(3.179)\end{array}$ & $\begin{array}{l}-0.005 \\
(0.034)\end{array}$ \\
\hline roe & $\begin{array}{c}0.060 * * * \\
(0.023)\end{array}$ & $\begin{array}{c}0.000 * * * \\
(0.000)\end{array}$ & $\begin{array}{c}0.057 * * * \\
(0.012)\end{array}$ & $\begin{array}{c}0.000 * * * \\
(0.000)\end{array}$ \\
\hline pro_gdp & $\begin{array}{c}-0.0003 * * * \\
(0.00002)\end{array}$ & $\begin{array}{l}-0.00000 \\
(0.00000)\end{array}$ & $\begin{array}{l}-0.00000 \\
(0.00001)\end{array}$ & $\begin{array}{c}0.00000 \\
(0.00000)\end{array}$ \\
\hline numoffirms & $\begin{array}{c}0.040 * * * \\
(0.013)\end{array}$ & $\begin{array}{c}-0.00005^{*} \\
(0.00003)\end{array}$ & $\begin{array}{l}-0.002 \\
(0.004)\end{array}$ & $\begin{array}{c}0.00002 \\
(0.00004)\end{array}$ \\
\hline Observations & 12,962 & 11,625 & 5,436 & 5,687 \\
\hline $\mathrm{R} 2$ & 0.028 & 0.626 & 0.010 & 0.678 \\
\hline Adjusted R2 & -0.125 & 0.561 & -0.138 & 0.633 \\
\hline F Statistic & $46.688 * * *$ & $2,371.199 * * *$ & $6.692 * * *$ & $1,499.066^{* * *}$ \\
\hline
\end{tabular}

\subsection{Crowd-out effect in different districts}

We want to know whether the district of firms can affect the crowd-out effect by government debt. We classified provinces of listed firms in our data into four districts: northwest, southwest, southeast and northeast. Northwest: Gansu, Ningxia, Inner Mongolia; Southwest: Chongqing, Guangxi, Guizhou; Southeast: Guangdong, Hainan Hubei, Hunan, Anhui, Fujian, Jiangsu, Jiangxi; Northeast: Beijing, Hebei, Heilongjiang, Henan, Jilin, Liaoning. We find that the crowd-out effect is not significant in northwest and southwest region (because of the relevantly small number of observations). The effect of local government debt on firm is significantly negative in southeast region but significantly positive in northeast region. We think that southeast region has a more efficient market than northeast region, so southeast companies can transfer to equity financing more easily than northeast region. What's more, many SOE companies are located in northeast region, so the defending effect of SOE will be shown more in northeast subsample.

Table4. Crowd-out effect in different districts

\begin{tabular}{|c|c|c|c|c|}
\hline & northwest & southwest & southeast & northeast \\
\hline & \multicolumn{3}{|c|}{ Leverage2 } & \multirow[b]{2}{*}{ (4) } \\
\hline & $(1)$ & (2) & (3) & \\
\hline \multirow[t]{2}{*}{ lngovdebt } & 0.006 & -0.006 & $-0.021 * * *$ & $0.005 * * *$ \\
\hline & $(0.006)$ & $(0.004)$ & $(0.001)$ & $(0.001)$ \\
\hline \multirow[t]{2}{*}{ size } & $-0.176^{* * *}$ & $-0.122 * * *$ & $-0.130 * * *$ & $-0.144 * * *$ \\
\hline & $(0.009)$ & $(0.006)$ & $(0.001)$ & $(0.002)$ \\
\hline \multirow[t]{2}{*}{ tangibility } & $-0.002 * * *$ & $-0.0001 * * *$ & $-0.0001 * * *$ & $-0.0003 * * *$ \\
\hline & $(0.001)$ & $(0.00003)$ & $(0.00001)$ & $(0.0001)$ \\
\hline \multirow[t]{2}{*}{ soe } & $0.093 * *$ & $0.059 * *$ & $0.052 * * *$ & $0.025 * *$ \\
\hline & $(0.039)$ & $(0.025)$ & $(0.009)$ & $(0.012)$ \\
\hline \multirow[t]{2}{*}{ regulate } & $0.438 * * *$ & 0.003 & -0.002 & 0.005 \\
\hline & $(0.124)$ & $(0.044)$ & $(0.020)$ & $(0.026)$ \\
\hline \multirow[t]{2}{*}{ roe } & $0.000 * * *$ & $0.000 * * *$ & $0.000 * * *$ & $0.000 * * *$ \\
\hline & $(0.000)$ & $(0.000)$ & $(0.000)$ & $(0.000)$ \\
\hline \multirow[t]{2}{*}{ pro_gdp } & $0.00001 * *$ & $0.00000 * * *$ & $-0.00000 * * *$ & 0.00000 \\
\hline & $(0.00000)$ & $(0.00000)$ & $(0.00000)$ & $(0.00000)$ \\
\hline \multirow[t]{2}{*}{ numoffirms } & 0.002 & $-0.008 * * *$ & $-0.00004 *$ & $0.0004 * * *$ \\
\hline & $(0.005)$ & $(0.001)$ & $(0.00002)$ & $(0.0001)$ \\
\hline Observations & 542 & 890 & 11,156 & 4,724 \\
\hline $\mathrm{R} 2$ & 0.682 & 0.659 & 0.672 & 0.638 \\
\hline Adjusted R2 & 0.635 & 0.611 & 0.624 & 0.588 \\
\hline F Statistic & $126.508 * * *$ & $188.152 * * *$ & $2,492.553 * * *$ & $914.024 * * *$ \\
\hline
\end{tabular}




\section{Robustness test}

\subsection{Subperiod Regression}

Because of the low quality of firm-level data before 2008 and Four Trillion Plan in 2008.11, the sample is divided into two subperiods: 2000-2009,2010-2018. The $r$ regression results show that the negative association between the firm leverage and government debt remains strong after 2010, which supports the main hypothesis of this paper. However, the financial crisis that broke out in 2008 and the four trillion support plan, in addition to its subsequent impact in 2009 made the correlation between the firm leverage and government debt not significant. Before 2008, the small sample size also affected the results. Thus, the association between the firm leverage and government debt is not significant during 2000 to 2009 .

Table5. Crowd-out effect in subperiod sample

\begin{tabular}{ccc}
\hline & $2000-2009$ & $2010-2018$ \\
\cline { 2 - 3 } & $(1)$ & $(2)$ \\
\hline lngoverage 1 & $-0.714 * * *$ \\
size & -0.154 & $(0.204)$ \\
& $(0.482)$ & $-6.195^{* * *}$ \\
tangibility & $6.709^{* * *}$ & $(0.561)$ \\
& $(1.897)$ & 1.828 \\
soe & 9.814 & $(4.165)$ \\
& $(6.451)$ & $-8.544 * * *$ \\
regulate & -0.305 & $(2.247)$ \\
& $(1.835)$ & $-6.845^{*}$ \\
roe & & $(3.962)$ \\
& & $0.102 * * *$ \\
pro_gdp & 0.098 & $(0.014)$ \\
& $(0.079)$ & $-0.0001^{* * *}$ \\
numoffirms & $-0.0001 * * *$ & $(0.00001)$ \\
& $(0.00001)$ & $0.044 * * *$ \\
Observations & -0.009 & $(0.009)$ \\
R & $(0.009)$ & 16,822 \\
Adjusted $\mathrm{R}^{2}$ & 1,576 & 0.021 \\
F Statistic & 0.135 & -0.129 \\
& -5.679 & $38.362^{* * *}$ \\
\hline & $4.547 * * *$ &
\end{tabular}

\subsection{Instrument variables}

We use govdebt_gdp (government debt divided province GDP) to replace the local government debt to eliminate the influence of different economic development conditions in different provinces. The results show that after excluding the effects of provincial difference, the relationship between local government loan and firm debt is still significantly negative. In the selection of the second instrument variable, we use the natural logarithm of the lagging one period of government debt as the independent variable and observe the lagging effect of government debt on corporate firm-level leverage. The results show that there is a significantly negative correlation between lagging one period of firm leverage and local government debt.

Table6. Robustness test using instrument variables

\begin{tabular}{|c|c|c|c|c|}
\hline & \multicolumn{3}{|c|}{ Dependent variable: } & \multirow[b]{2}{*}{$\begin{array}{c}\text { leverage } 2 \\
(4)\end{array}$} \\
\hline & $\begin{array}{c}\text { leverage1 } \\
\text { (1) }\end{array}$ & $\begin{array}{c}\text { leverage } 2 \\
(2)\end{array}$ & $\begin{array}{l}\text { leverage1 } \\
\text { (3) }\end{array}$ & \\
\hline govdebt gdp & $\begin{array}{c}-1,630.351 * * * \\
(476.460)\end{array}$ & $\begin{array}{c}-15.244 * * * \\
(1.270)\end{array}$ & & \\
\hline $\log ($ lagdebt $)$ & & & $\begin{array}{c}-1.070 * * * \\
(0.271)\end{array}$ & $\begin{array}{c}-0.013 * * * \\
(0.001)\end{array}$ \\
\hline size & $\begin{array}{c}-8.633 * * * \\
(0.712)\end{array}$ & $\begin{array}{c}-0.136 * * * \\
(0.001)\end{array}$ & $\begin{array}{c}-9.151 * * * \\
(0.723)\end{array}$ & $\begin{array}{c}-0.139 * * * \\
(0.001)\end{array}$ \\
\hline tangibility & $\begin{array}{c}10.240^{*} \\
(5.393)\end{array}$ & $\begin{array}{c}-0.0001 * * * \\
(0.00001)\end{array}$ & $\begin{array}{l}10.556^{*} \\
(5.391)\end{array}$ & $\begin{array}{c}-0.0001 * * * \\
(0.00001)\end{array}$ \\
\hline soe & $\begin{array}{l}-2.526 \\
(2.694)\end{array}$ & $\begin{array}{c}0.063 * * * \\
(0.007)\end{array}$ & $\begin{array}{l}-2.946 \\
(2.691)\end{array}$ & $\begin{array}{c}0.059 * * * \\
(0.007)\end{array}$ \\
\hline regulate & $\begin{array}{l}-6.478 \\
(5.346)\end{array}$ & $\begin{array}{c}0.017 \\
(0.015)\end{array}$ & $\begin{array}{l}-7.190 \\
(5.349)\end{array}$ & $\begin{array}{c}0.007 \\
(0.015)\end{array}$ \\
\hline roe & $0.080 * * *$ & $0.000 * * *$ & $0.079 * * *$ & $0.000 * * *$ \\
\hline
\end{tabular}




\begin{tabular}{ccccc} 
& $(0.019)$ & $(0.000)$ & $(0.019)$ & $(0.000)$ \\
pro gdp & $-0.0002 * * *$ & $-0.00000^{* * *}$ & $-0.0002 * * *$ & 0.000 \\
& $(0.00002)$ & $(0.00000)$ & $(0.00002)$ & $(0.00000)$ \\
numoffirms & $0.042 * * *$ & $-0.00005 * *$ & $0.051 * * *$ & -0.00000 \\
& $(0.010)$ & $(0.00002)$ & $(0.009)$ & $(0.00002)$ \\
\hline Observations & 18.398 & 17.312 & 18.398 & 17.312 \\
R2 & 0.022 & 0.634 & 0.022 & 0.638 \\
Adjusted R2 & -0.113 & 0.582 & -0.113 & 0.586 \\
\hline
\end{tabular}

\section{Conclusion and Policy Implication}

We investigate the impact of government debt on firms' capital structure decision using firm-level data on all provinces in China between 2000-2018. We argue that China's local government debt financing has a significant crowd-out influence on firm leverage. However, the effect differs between SOEs and non-SOEs, we find that the crowded-out effect is not significant for SOEs, while has the opposite result in non-SOEs. Moreover, we find that larger firms can defend crowd-out effect of government debt better than smaller firms. The effect of local government debt on firm is significantly negative in southeast region but significantly positive in northeast region. To address the concern of endogenous issue, we use two instrument variables to replace the independent variable lngovdebt. One is the lagged government debt and the other is to divide the government debt by the provincial GDP. To do the robustness test, we run the regressions under 2 subperiods and the results are still robust.

There are rich policy implications in this study: The government investment, state-owned sectors and misallocated resources between firms with different ownership types, jointly characterize the China-style growth which results in not only its past successes but also current problems. First, properly adjust the relationship between the local and central governments and improve the national financial governance system. Second, deleveraging should take into account the negative externalities of systemic risk, and the micro-policy should be more precise to properly resolve the financial risks of listed companies.

\section{Reference}

1. Campello, M., Debt Financing: Does it Boost or Hurt Firm Performance in Product Markets? Journal of Financial Economics, Vol. 82, No.1, 2006, pp.135172.

2. Demirci I, Huang J, Sialm C, et al. Government Debt and Corporate Leverage: International Evidence[J]. Journal of Financial Economics, 2019, 133(2): 337356.

3. Elmendorf D.W. \& Mankiw N.G. (1999). Government debt. In: Taylor J.B. \& Watson M.W. (eds), Handbook of Macroeconomics, Vol.1. Britain: Elsevier, 1615- 1669.

4. FanG. \& LvY. (2012). Fiscalprudenceandgrowthsustainability: Ananalysis of China'spu blicdebts. Asian Economic Policy Review, 7 (2), 202-220.
5. Friedman, Benjamin M. "Crowding Out or Crowding In? Economic Consequences of Financing Government Deficits." Brookings Papers on Economic Activity, vol. 1978, no. 3, 1978,

6. Graham J R, Leary M T, Roberts M R. A Century of Capital Structure: The Leveraging of Corporate America [J]. Journal of Financial Economics, 2015, 118 (3) : 658-683

7. Huang, G., and Song, F. M., 2006, “The Determinants of Capital Structure: Evidence From China", China Economic Review, 17 (1): 14-36.

8. Huang Y. \& Wang X. (2017). Building an efficient financial system in China: In need of stronger market discipline. Asian Economic Policy Review, 12 (2), 188-205.

9. Krishnamurthy A. \& Vissing-Jorgensen A.(2012).The aggregate demand for treasury debt. Journal of Political Economy, 120 (2), 233-267.

10. Li, K., Yue, H., and Zhao, L., 2009, "Ownership, Institutions, and Capital Structure: Evidence From China", Journal of Comparative Economics, 37 (3): $471-490$.

11. Liang Y, Shi K, Wang L, et al. Local Government Debt and Firm Leverage: Evidence from China[J]. Asian Economic Policy Review, 2017, 12(2): 210232

12. Lin J Y, Li Y. Export and Economic Growth in China: A Demand-oriented Analysis[J]. China Economic Quarterly, 2003.

13. Ouyang M. \& Peng Y. (2015). The treatment-effect estimation: A case study of the 2008 economic stimulus package of China. Journal of Econometrics, 188 (2), 545-557.

14. Shen G, Chen B. Zombie firms and over-capacity in Chinese manufacturing $[\mathrm{J}]$. China Economic Review, 2017: 327-342.

15. Liang Y, Shi K, Wang L, et al. Local Government Debt and Firm Leverage: Evidence from China[J]. Asian Economic Policy Review,20 